Biberdžić, M., Lalević, D., Ilić, Z., Milenković, L., Vuković, A., Barać, S., Madić, M., Miladinović, B. (2021): The influence of the variety and different doses of nitrogen on the grain yield and protein content in triticale grain. Agriculture and Forestry, 67 (4): 35-42. doi: 10.17707/AgricultForest.67.4.03

DOI: 10.17707/AgricultForest.67.4.03

Milan BIBERDŽIĆ $C^{l}$ Dragana LALEVIĆ ${ }^{*}$, Zoran S. ILIĆ', Lidija MILENKOVIĆ $C^{\prime}$, Aleksandar VUKOVIĆ ${ }^{l}$, Saša BARAĆ Milomirka MADIĆ ${ }^{2}$, Branislav MILADINOVIĆ

\title{
THE INFLUENCE OF THE VARIETY AND DIFFERENT DOSES OF NITROGEN ON THE GRAIN YIELD AND PROTEIN CONTENT IN TRITICALE GRAIN
}

\section{SUMMARY}

Observed through agronomic and economic significance, cereals represent the most important group of field plants, and the protein content in grain is the most important chemical parameter of complex grain quality. The research was conducted in order to determine the influence of the variety and different doses of nitrogen on the grain yield and protein content in triticale grain. The experiment, set up according to a random block system in four replications on eutric cambisol soil in the north of Montenegro, included five varieties of winter triticale (Odyssey, Kg-20, Triumph, Rtanj and Tango).

In addition to the control (variant without fertilization), four more fertilization variants were applied. The results of the research showed that the application of fertilizers has a significant influence on the values of the observed traits on the one hand, but also that the grain yield and protein content in the grain is largely conditioned by the genotype. In this regard, the highest average protein content in the grain had the variety Triumph in both tested years. The protein content of all tested varieties was significantly lower in the control variant compared to the fertilized variants. The highest grain yield in the first year had the variety Tango while the highest yielding variety in the second year was variety Rtanj.

Keywords: Triticale, Fertilization, Variety, Grain yield, Protein content

\footnotetext{
${ }^{1}$ Milan Biberdžić., Dragana Lalević *(Corresponding author: dragana.lalevic@pr.ac.rs), Zoran S. Ilić, Lidija Milenković, Aleksandar Vuković, Saša Barać, University in Priština, Faculty of Agriculture, Kopaonička bb, 38219 Lešak, SERBIA

2 Milomirka Madić, University of Kragujevac, Faculty of Agronomy in Čačak, Cara Dušana 34, 32102 Čačak, SERBIA

${ }^{3}$ Branislav Miladinović, Forest Administration of Montenegro, Miloša Tošića 4, 84210 Pljevlja, MONTENEGRO

Paper presented at the $12^{\text {th }}$ International Scientific Agricultural Symposium "AGROSYM 2021". Notes: The authors declare that they have no conflicts of interest. Authorship Form signed online. 


\section{INTRODUCTION}

Triticale, a hybrid created by crossing wheat and rye, combined the positive characteristics of the parent species. Thus, he inherited the ability to survive strong frosts from rye, and high genetic potential for yield and increased tolerance to diseases from wheat. The method of using triticale is largely conditioned by the characteristics of the variety. In this regard, large and uniform grain varieties with increased content of total proteins in relation to starch, are used for the preparation of concentrated fodder, while varieties that form a large biomass, such as rye, are used to store bulky fodder in the form of silage, hay or fresh masses (Glamočlija et al., 2018).

Thanks to the high content of essential amino acids, certain minerals and vitamins, the grain of triticale can satisfy a significant part of the needs in the diet of domestic animals. What sets triticale apart from other cereals is the higher yield, faster growth in the spring and the possibility of longer use as green fodder because the above-ground mass roughens later compared to rye or oats. In addition to being grown as a pure crop, triticale can also be sown in various mixtures with winter and spring legumes, which further increases its nutritional value (Schwarte et al., 2005).

The quality of triticale is conditioned by genotype, environmental conditions (Salehi and Arzani, 2013) and their interaction and can be improved by the application of nitrogen fertilizers. The application of nitrogen fertilizers in the diet of triticale contributes to the increase of its productivity (Lestingi et al., 2010), at the same time influencing the increase of the content of crude proteins and non-protein nitrogen (Zečević et al., 2009). Increasing the amount of nitrogen affects the improvement of the technological quality of triticale varieties (Zečević et al., 2010). Insufficient supply of soil with nutrients results in a shortening of the period of grain formation and pouring, which negatively affects the yield and grain quality. Nitrogen fertilization has the greatest impact on the protein content of the grain. Increasing the dose of nitrogen fertilizer contributes to the increased accumulation of protein in the grain, while the intake of small doses of nitrogen can reduce the protein content. The nitrogen content in the grain, among other things, depends on the mutual relationship of nutrients in the applied fertilizers. Thus, the use of nitrogen with potassium and NPK - fertilizers with a nutrient ratio of 1:1 increases the protein content in the grain, while the increased share of other nutrients in relation to nitrogen reduces the protein content (Tyrone, 2002; Jelić et al., 2004; Lalevic et al., 2019).

\section{MATERIAL AND METHODS}

The study was performed at the Sutivan site, in the north of Montenegro, during two consecutive seasons (2010/11 and 2011/12). The soil type was eutric cambisol. In both years, the mean temperature was higher than $30 \mathrm{yr}$ average (Table 1). The basic processing and pre-sowing preparation of the soil was done using standard method. 
The experiment was set up by random block system in four repetitions, with the size of an elementary plot of $6 \mathrm{~m}^{2}(3 \times 2 \mathrm{~m})$, including 5 cultivars (Odyssey, Kg-20, Triumph, Rtanj and Tango) of winter triticale ( $\times$ Triticosecale Wittmack). The study included the following varieties of fertilizers: unfertilized plot ( 0 - the control) and four variants of fertilization $\left(\mathrm{a}-60 \mathrm{~kg} \mathrm{ha}^{-1} \mathrm{~N}, \mathrm{~b}-60 \mathrm{~kg}\right.$ $\mathrm{ha}^{-1} \mathrm{~N}, 80 \mathrm{~kg} \mathrm{ha}^{-1} \mathrm{P}_{2} \mathrm{O}_{5}, 80 \mathrm{~kg} \mathrm{ha}^{-1} \mathrm{~K}_{2} \mathrm{O} ; \mathrm{c}-90 \mathrm{~kg} \mathrm{ha}^{-1} \mathrm{~N}, 80 \mathrm{~kg} \mathrm{ha}^{-1} \mathrm{P}_{2} \mathrm{O}_{5}, 80 \mathrm{~kg}$ $\mathrm{ha}^{-1} \mathrm{~K}_{2} \mathrm{O}$ and d - $120 \mathrm{~kg} \mathrm{ha}^{-1} \mathrm{~N}, 80 \mathrm{~kg} \mathrm{ha}^{-1} \mathrm{P}_{2} \mathrm{O}_{5}, 80 \mathrm{~kg} \mathrm{ha}^{-1} \mathrm{~K}_{2} \mathrm{O}$ ). Phosphorus and potassium were used in equal amounts $\left(80 \mathrm{~kg} \mathrm{ha}^{-1}\right)$ before the sowing period, while nitrogen was used in small amounts before the sowing period, and the rest of the planned amount was used as fertilization at the end of March. Sowing (550 grains per $\mathrm{m}^{2}$ ) was done by hand, during the optimal planting period (17.10.2010, 18.10.2011.) with a row spacing of $12 \mathrm{~cm}$.

The samples for analysis were taken at the stage of full maturity of crops. The spikes were hardened, dried and ground to determine the total nitrogen content by the Kjedahl method. Protein content was calculated by multiplying the concentration of total nitrogen in the grain by a coefficient of 6.25 .

The obtained results were statistically processed by the method of analysis of variance, where the significance of the difference of mean treatment (fertilization variant) was tested by LSD test using WASP 2.0. statistical package.

\section{Soil and meteorological conditions}

Before setting up the experiment, the soil samples from two depths from 0 to $10 \mathrm{~cm}$ and from 10 to $30 \mathrm{~cm}$ were taken at seeding, air-dried and analized for $\mathrm{pH}, \mathrm{CaCO}_{3}$, humus and available phosphorus and potassium.

Samples were analysed in the Agrochemical Laboratory of the Centre for Cereal Grains in Kragujevac. The applied soil testing methods were adopted by the Yugoslav Society for Soil Studies (JDPZ).

The soil on which the experiment was set up is acid $\left(\mathrm{pH} \mathrm{H}_{2} \mathrm{O}=5.61-5.53\right)$, weakly carbonate (content of total carbonates $2.4-2.44 \%$ ), quite humus (3.35$3.96 \%)$ and poorly supplied with phosphorus (5.12-4.24 mg $100 \mathrm{~g}^{-1}$ soil) and

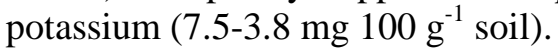

The analysis of meteorological conditions during the two - year research showed that the temperature conditions, but also the amount of precipitation had a certain influence on the values of the observed traits in the selected genotypes of triticale included in the research. The amount of precipitation in the second year of the study was $212.8 \mathrm{~mm}$ lower than the amount of precipitation measured during the vegetation period in the first year of the study.

In both years of the research, the measured amount of precipitation was lower compared to the multi-year average. The production year 2011/12 was marked by significantly lower amounts of precipitation in October, November and December, in the period of sowing, germination and initial growth of plants compared to the production year 2010/11, but also the multi-year average. A smaller amount of precipitation during the second year of the survey, compared to 
the first year and the multi-year average, was recorded during March, April and May.

In contrast to the amount of precipitation, the average air temperatures for the observed period in both years of the research were higher in relation to the multi-year average. Thus, the average air temperature for the period October-July in the first year of the research was $1.7^{\circ} \mathrm{C}$, and in the second $1.2^{\circ} \mathrm{C}$ higher than the multi-year average (Table 1).

Table 1. Mean monthly air temperature $\left({ }^{\circ} \mathrm{C}\right)$ and monthly rainfall during the growing seasons of experimental years and long term average (1961-1990)

\begin{tabular}{|c|c|c|c|c|c|c|c|c|c|c|c|}
\hline \multirow[t]{2}{*}{ Year } & \multicolumn{10}{|c|}{ Months } & \multirow[t]{2}{*}{ Sum } \\
\hline & $\mathrm{X}$ & XI & XII & I & II & III & IV & $\mathrm{V}$ & VI & VII & \\
\hline \multicolumn{12}{|c|}{ Monthly rainfall (mm) } \\
\hline 2010-- & 65.3 & 130.7 & 147.3 & 36.0 & 76.0 & 30.9 & 45.6 & 120.8 & 33.2 & 78.8 & 764.8 \\
\hline 2011-12 & 36.2 & 7.4 & 54.6 & 78.7 & 182.7 & 56.7 & 47.6 & 46.2 & 34.2 & 7.7 & 552.0 \\
\hline 1961-90 & 80 & 115 & 91 & 87 & 68 & 60 & 70 & 76 & 72 & 64 & 783 \\
\hline \multicolumn{11}{|c|}{ Average monthly temperatures $\left({ }^{\circ} \mathrm{C}\right)$} & Average \\
\hline 2010-11 & 10.1 & 8.5 & 2.0 & -0.6 & 0.9 & 6.0 & 10.5 & 14.5 & 18.9 & 21.2 & 9.2 \\
\hline 2011-12 & 9.3 & 3.2 & 2.2 & -1.7 & -3.5 & 5.9 & 10.8 & 15.0 & 20.7 & 24.6 & 8.7 \\
\hline$\overline{1961-90}$ & 9.4 & 4.7 & 0.2 & -1.3 & 0.7 & 4.9 & 9.0 & 13.3 & 16.3 & 17.9 & 7.5 \\
\hline
\end{tabular}

\section{RESULTS AND DISCUSSION}

Grain yield is the surest indicator of differences in productivity between varieties and their specificity in terms of mineral nutrition, and therefore the yields achieved have the highest practical value for each variety. Data on the realized yields of the tested varieties during the two - year trial are presented in Table 2.

The data in the table show that the average yield, observed for all examined cultivars and fertilization variants in the second year, which can be considered more unfavorable in terms of meteorological conditions, was significantly very lower compared to the first and amounted to $3.95 \mathrm{t} \mathrm{ha}^{-1}$.

All cultivars achieved the lowest grain yield on the variant without fertilization in both years of testing and it was significantly very lower in relation to the grain yield achieved on the variants that involved the use of mineral fertilizers. Average values show that the use of the highest amount of nitrogen in combination with phosphorus and potassium, in both years, led to the highest yields.

However, the difference in yield between the use of the lowest and highest amount of nitrogen in combination with nitrogen and phosphorus was not statistically significant. 
Table 2. Grain yield of winter triticale depending of variety and different doses of nitrogen $\left(\mathrm{t} \mathrm{ha}^{-1}\right)$

\begin{tabular}{|c|c|c|c|c|c|c|c|}
\hline \multirow[t]{2}{*}{ Year $(C)$} & \multirow{2}{*}{$\begin{array}{l}\text { Variety } \\
\text { (A) }\end{array}$} & \multicolumn{5}{|c|}{ Fertilization variant (B) } & \multirow[t]{2}{*}{ Average } \\
\hline & & 0 & $\mathrm{a}$ & $\mathrm{b}$ & $\mathrm{c}$ & $\mathrm{d}$ & \\
\hline \multirow{5}{*}{ 2010/11 } & Odissey & 3,15 & 3,85 & 4,69 & 4,68 & 4,97 & 4,27 \\
\hline & Kg-20 & 2,67 & 3,62 & 4,34 & 4,42 & 4,45 & 3,9 \\
\hline & Triumph & 3,44 & 4,38 & 5,27 & 5,21 & 5,37 & 4,73 \\
\hline & Rtanj & 3,36 & 4,55 & 5,26 & 5,37 & 5,62 & 4,83 \\
\hline & Tango & 3,67 & 4,71 & 5,70 & 5,75 & 6,05 & 5,18 \\
\hline Average & & 3,26 & 4,22 & 5,05 & 5,08 & 5,29 & 4,58 \\
\hline \multirow{5}{*}{ 2011/12 } & Odissey & 2,55 & 3,43 & 4,08 & 4,41 & 4,42 & 3,78 \\
\hline & Kg-20 & 2,43 & 3,24 & 3,79 & 3,88 & 4,12 & 3,49 \\
\hline & Triumph & 2,90 & 3,77 & 4,56 & 4,53 & 4,69 & 4,09 \\
\hline & Rtanj & 2,92 & 3,84 & 4,97 & 4,83 & 4,67 & 4,25 \\
\hline & Tango & 3,03 & 3,77 & 4,49 & 4,77 & 4,68 & 4,15 \\
\hline Average & & 2,77 & 3,61 & 4,38 & 4,48 & 4,51 & 3,95 \\
\hline $\begin{array}{l}\text { Two year } \\
\text { aver. }\end{array}$ & & 3,01 & 3,91 & 4,71 & 4,78 & 4,90 & 4,26 \\
\hline
\end{tabular}

Anova Table

Source of variation

Replication

Factor A

Factor B

Factor C

AxB

$\mathrm{AxC}$

$\mathrm{BxC}$

$\mathrm{AxBxC}$

Error

Degrees of
freedom

F cal.

2

Total

\section{4}

4

1

16

4

4

16

98

149

\begin{tabular}{cccccccc}
\hline LSD & A & B & C & AxB & AxC & BxC & AxBxC \\
\hline 0,05 & 0,186 & 0,186 & 0,118 & 0,416 & 0,263 & 0,263 & 0,588 \\
\hline 0,01 & 0,246 & 0,246 & 0,156 & 0,551 & 0,348 & 0,348 & 0,779 \\
\hline
\end{tabular}

Our results are similar to those obtained by Piekarczyk et al. (2011) which founded only minor increase in grain yield as a result of the application of nitrogen at the dose of 40 to $160 \mathrm{~kg} \mathrm{ha}^{-1}$. As the most productive varieties, Tango in the first year (average yield was $5.18 \mathrm{t} \mathrm{ha}^{-1}$ ) and Rtanj in the second year of testing (average yield was $4.25 \mathrm{t} \mathrm{ha}^{-1}$ ) stood out, with the difference in yield between varieties Tango, Rtanj and Trijumf did not show statistical significance. Variety Kg-20 had the lowest average yield in both years of testing. Our results are in accordance with results of Kara and Uysal (2009), Ivanova and Kirchev (2014), Djuric et al. (2015), Biberdzic et al. (2017), Madic et al. (2018), Lalevic 
et al. (2020) and Bielski et al. (2020) which pointed out that the level of yield depends largely on meteorological conditions during the growing season and on mineral fertilization (Dumbrava et al., 2016). Also, Kara and Uysal (2009) state that with low moisture, $\mathrm{N}$ fertilization will have minor effects on crop yield, since, yield is more limited by moisture than by $\mathrm{N}$ supply.

Table 3. Protein content of winter triticale depending of variety and different doses of nitrogen $(\%)$

\begin{tabular}{|c|c|c|c|c|c|c|c|}
\hline \multirow[t]{2}{*}{ Year $(C)$} & \multirow{2}{*}{$\begin{array}{l}\text { Variety } \\
\text { (A) }\end{array}$} & \multicolumn{5}{|c|}{ Fertilization variant (B) } & \multirow{2}{*}{ Average } \\
\hline & & 0 & $\mathrm{a}$ & $\mathrm{b}$ & $\mathrm{c}$ & $\mathrm{d}$ & \\
\hline \multirow{5}{*}{ 2010/11 } & Odissey & 12,31 & 15,87 & 14,68 & 14,62 & 13,56 & 14,21 \\
\hline & Kg-20 & 12,15 & 15,21 & 14,50 & 14,20 & 13,68 & 13,95 \\
\hline & Triumph & 12,78 & 16,62 & 15,37 & 15,10 & 14,18 & 14,81 \\
\hline & Rtanj & 11,87 & 14,06 & 13,49 & 13,55 & 13,12 & 13,22 \\
\hline & Tango & 11,84 & 13,75 & 13,43 & 13,85 & 13,18 & 13,21 \\
\hline Average & & 12,19 & 15,10 & 14,29 & 14,26 & 13,54 & 13,88 \\
\hline \multirow{5}{*}{ 2010/11 } & Odissey & 10,72 & 13,62 & 13,37 & 13,32 & 13,46 & 12,89 \\
\hline & Kg-20 & 12,53 & 13,93 & 13,18 & 13,06 & 13,08 & 13,15 \\
\hline & Triumph & 12,18 & 14,65 & 13,62 & 13,03 & 12,81 & 13,26 \\
\hline & Rtanj & 11,03 & 13,06 & 12,43 & 12,34 & 12,28 & 12,23 \\
\hline & Tango & 11,12 & 12,90 & 12,48 & 12,12 & 12,61 & 12,25 \\
\hline Average & & 11,52 & 13,63 & 13,02 & 12,77 & 12,84 & 12,76 \\
\hline $\begin{array}{l}\text { Two year } \\
\text { average }\end{array}$ & & $\mathbf{1 1 , 8 5}$ & 14,36 & 13,65 & 13,51 & 13,19 & 13,31 \\
\hline
\end{tabular}

\begin{tabular}{|c|c|c|c|c|c|c|c|}
\hline \\
\hline \multirow{2}{*}{\multicolumn{2}{|c|}{$\begin{array}{l}\text { Source of } \\
\text { variation } \\
\text { Replication }\end{array}$}} & \multicolumn{3}{|c|}{$\begin{array}{c}\text { Degrees of freedom } \\
2\end{array}$} & \multirow{2}{*}{\multicolumn{3}{|c|}{$\begin{array}{c}\text { F cal. } \\
-\end{array}$}} \\
\hline & & & & & & & \\
\hline \multicolumn{2}{|l|}{ Factor A } & \multicolumn{3}{|c|}{4} & \multicolumn{3}{|c|}{69,952} \\
\hline \multicolumn{2}{|l|}{ Factor B } & \multicolumn{3}{|c|}{4} & \multicolumn{3}{|c|}{32,019} \\
\hline \multicolumn{2}{|l|}{ Factor C } & \multicolumn{3}{|c|}{1} & \multicolumn{3}{|c|}{7,322} \\
\hline \multicolumn{2}{|l|}{ AxB } & \multicolumn{3}{|c|}{16} & \multicolumn{3}{|c|}{35,895} \\
\hline \multirow{2}{*}{\multicolumn{2}{|c|}{$\mathrm{AxC}$}} & \multicolumn{3}{|c|}{4} & \multicolumn{3}{|c|}{30,695} \\
\hline BxC & & \multirow{2}{*}{\multicolumn{3}{|c|}{$\begin{array}{c}4 \\
16\end{array}$}} & \multicolumn{3}{|c|}{16,891} \\
\hline \multicolumn{2}{|l|}{$\mathrm{AxBxC}$} & & & & \multicolumn{3}{|c|}{25,986} \\
\hline \multicolumn{2}{|l|}{ Error } & \multicolumn{3}{|c|}{98} & \multirow{2}{*}{\multicolumn{3}{|c|}{$\begin{array}{l}- \\
-\end{array}$}} \\
\hline Total & & \multicolumn{3}{|c|}{149} & & & \\
\hline LSD & A & B & $\mathrm{C}$ & $\mathrm{AxB}$ & $\mathrm{AxC}$ & $\mathrm{BxC}$ & $\mathrm{AxBxC}$ \\
\hline 0,05 & 0,340 & 0,340 & 0,215 & 0,760 & 0,481 & 0,481 & 1,075 \\
\hline 0,01 & 0,450 & 0,450 & 0,285 & 1,007 & 0,637 & 0,637 & 1,424 \\
\hline
\end{tabular}

The biological value of triticale is mainly due to the high levels of protein in the grain. The protein content in the grain is a property of the genotype and its inheritance is controlled by factors of a complex nature, and the content largely 
depends on environmental conditions (Đekić et al., 2010) and mineral nutrition (Dobreva, 2016).

The data in Table 3 show that the use of mineral fertilizers, in both years of testing, led to a significantly very large increase in grain protein content in all cultivars included in the study. Also, it was noticed that all varieties achieved the highest protein content in the variant of fertilization where only nitrogen was used in the amount of $60 \mathrm{~kg} \mathrm{ha}^{-1}$. If we talk about the influence of the variety on the protein content in the grain, we can notice that in both years of research, the highest content of protein in the grain was registered with the variety Triumph. Also, we can notice that all varieties achieved higher protein content in the first year of research, which can be assessed as more favorable in terms of climatic conditions. Our results are in accordance with the results of Alaru et al. (2003), Lestingi et al. (2010) and Wojtkowiak et al. (2013) which pointed out that cultivar was the main factor influencing the content of protein in triticale grain, that weather conditions in the growth period have a lesser impact and nitrogen fertilization being the least important. In accordance with the opinion of these authors fertilization with nitrogen at tillering stage caused an average increase in the protein content in the grain of triticale and the optimal dose of nitrogen for maintaining good quality of triticale was under $60 \mathrm{~kg} \mathrm{ha}^{-1}$.

\section{CONCLUSIONS}

Higher grain yield as well as protein content in grain, all examined varieties, achieved in the first year, which was marked by moderate air temperatures at the time of grain filling and higher precipitation in the second part of the vegetation. The Tango variety had the highest yield in the first year, and the Rtanj variety in the second year, with the difference in the amount of yield between the mentioned varieties and the Triumph variety not being significant. The Kg-20 variety had the lowest total grain yield. The Triumph variety had the highest protein content in grain in both years of testing.

\section{REFERENCES}

Alaru, M., Laur, U., Jaama, E. (2003): Influence of nitrogen and weather contitions on the grain quality of winter triticale, Agronomy Research, 1: 3-10.

Biberdžić, M., Lalević, D., Barać, S., Stojković, S. (2017): Productive traits of triticale depending on sowing rate and meteorological conditions in tested years, Agriculture and Forestry, Vol. 63, Issue 1, 129-136.

Bielski, S., Romaneckas, K., Šarauskis, E. (2020): Impact of Nitrogen and Boron Fertilization on Winter Triticale Productivity Parameters, Agronomy, 10, 279: 1-12.

Dobreva, S. (2016): Triticale - past and future, Agricultural science and technology, Vol. 8, No. 4, p. 271-275. 
Dumbravă, M., Ion, V., Epure, L.I., Băşa, A.G., Ion, N., Duşa, E.M. (2016): Grain yield and yield components at triticale under different technological conditions, Agriculture and Agriculture Science Procedia, Vol. 10, p. 94-103.

Đekić, V., Staletić, M., Perišić, V., \& Glamočlija, Đ. (2009). Hemijski sastav kagujevačkih sorti tritikalea u periodu 2007-2008. godine, XIV Savetovanje o biotehnologiji sa međunarodnim učešćem, Čačak, Zbornik radova, 14 (15), 73-77.

Đekić, V., Milovanović, M., Staletić, M., Perišić, V. (2010): Investigation of yield components Kragujevac varieties winter triticale. Proceedings of research papers, 16, 1-2: 35-41.

Đurić, N., Cvijanović, G., Dozet, G., Matković, M., Đekić, V., Trkulja, V. (2015): New winter triticale species developed at Institute PKB Agroekonomik. Plant breeding and seed production, Vol. 21 (1), p. 10-17.

Glamočlija, N. Starčević, M., Ćirić, J., Šefer, D., Glišić, M., Baltić, M., Marković, R., Spasić, M., Glamočlija, Đ. (2018): The importance of triticale in animal nutrition, Veterinary Journal of Republic of Srpska (Banja Luka), Vol.XVIII, No.1, 73 -94.

Ivanova, A., Kirchev, H. (2014): Agronomy performance of new triticale varieties (xTriticosecale Wittmack) grown under different regions. Global Journal of Scientific Researches, 2 (3), p. 71-75.

Jelić, M., Dugalić, G., Milivojević, J., \& Živanović-Katić, S. (2004). Uticaj sistema mineralne ishrane na prinos zrna ozimog tritikalea. Acta Agriculturae Serbica, IX, 17, 493-499.

Kara, B. and Uysal, N. (2009): Influence on Grain Yield and Grain Protein Content of LateSeason Nitrogen Application in Triticale, Journal of Animal and Veterinary Advances, 8 (3): 579-586.

Lalević, D., Biberdžić, M., Ilić, Z., Milenković, L., Tmušić, N., Stojiljković, J. (2019): Effect of cultivar and increased nitrogen quantities on some productive traits of triticale. Agriculture and Forestry, 65 (4): 127-136

Lalević, D., Biberdžić, M., Milenković, L., Ilić, S. Z. (2020): Study of some productive quality and traits of triticale varieties in Montenegrin conditions, GEA (Geo Eco-Eco Agro) International Conference, 28-29 May 2020, Montenegro - Book of Proceedings, p. 289 $-296$.

Lestingi, A., Bovera, F., De Giorgio, D., Ventrella, D., Tateo, A. (2010): Effects of tillage and nitrogen fertilization on triticale grain yield, chemical composition and nutritive value. Journal of the science of food and agriculture, 90: 2440-2446.

Madić, M., Paunović, A., Đurović, D., Marković, G., Knežević, D., Jelić, M., Stupar, V. (2018): Grain yield and its components in triticale grown on a pseudogley soil. Journal of Central European Agriculture, 19(1), p. 184-193.

Piekarczyk, M., Jaskulski, D., Galęzewski, L. (2011): Effevt of nitrogen fertilization on yield and grain technological quality of some winter wheat cultivars grown on light soil. Acta Scientarium Polonorum Agricultura, 10(2): 87-95.

Salehi M. and Arzani A. (2013): Grain qu-ality traits in titicale influenced by field salinity stress, Australian Journal of Crop Science, 7(5): 580-587.

Schwarte, A. J., Gibson, L. R., Karlen, D. L., Liebman, M., Jannink, J. (2002): Planting date effects on winter triticale dry matter and nitrogen accumulation. Agron. Journal, 97: 1333-1341.

Tyrone, H., Lionel, M., \& Wal, A. (2002). Effects of nitrogen and phosphorus on the grain yield and quality of triticale. Acta Agronomica Hungarica, 48 (1), 41-49.

Wojtkowiak, A., Stępien, A., Tańska, M., Konopka, I., Konopka, S. (2013): Impact of nitrogen fertilization on the yield and content of protein fractions in spring triticale grain, African Journal of Agricultural Researc, Vol. 8(28): 3778-3783.

Zečević, V., Knežević, D., Bošković, J., Milenković, S. (2010): Effect of nitrogen and ecological factors on quality of winter triticale cultivars. Genetika, 42 (3): 465- 474. 